\section{Kidney \\ Blood Pressure Research}

\title{
Irisin and Volume Overload are Associated with Protein Energy Wasting in Peritoneal Dialysis Patients
}

\author{
Si-Jia Zhou Qing-Feng Han Ai-Hua Zhang Wen Tang Ling-Hua Sun \\ Department of Nephrology, Peking University Third Hospital, Beijing, China
}

\section{Key Words}

Irisin $•$ Volume overload $\bullet$ Protein energy wasting $•$ Peritoneal dialysis

\begin{abstract}
Background/Aims: Protein energy wasting (PEW) is a common medical phenomenon that is observed in maintenance dialysis patients. PEW also increases morbidity and mortality of these patients. Its pathogenesis is unclear. We hypothesize that serum irisin levels and volume overload may induce PEW in peritoneal dialysis (PD) patients. The aim of this study is to measure serum irisin levels, evaluate volume status of PD patients, and study their correlations with PEW in PD patients. Methods: This study is a cross-sectional study with 160 PD patients from the PD center of Peking University Third Hospital and 35 healthy control subjects. PD patients were divided into PEW group and non-PEW group according to PEW diagnosis criteria. Serum irisin concentrations were measured by ELISA. Volume overload status (volume overload is defined as overhydration value $\geq 2$ liters) of PD patients was analyzed by bioelectrical impedance. Results: The serum irisin levels were significantly lower in PD patients compared with those of the controls $(113.2 \pm 11.8 \mathrm{ng} / \mathrm{ml}$ vs. $464.2 \pm 37.4 \mathrm{ng} / \mathrm{ml}, \mathrm{P}<0.01)$. The serum irisin levels were lower in PD patients with PEW than those of the patients without PEW $(106.5 \pm 15.2 \mathrm{ng} / \mathrm{ml}$ vs. $117.4 \pm 17.6 \mathrm{ng} / \mathrm{ml}, \mathrm{P}<0.01)$. PEW is more prevalent in patients with volume overload than patients without volume overload $\left(62.5 \%\right.$ vs. $\left.43.1 \%, x^{2}=5.756, P=0.016\right)$; however, no direct relationship was found between irisin levels and volume overload status. The independent influencing factors of PEW were serum irisin, serum albumin, and volume overload. Conclusion: Our results are the first to provide clinical evidence of the association between serum irisin, volume overload, and PEW in PD patients. PEW may inhibit the release or synthesis of irisin from skeletal muscles, and volume overload may aggravate PEW in PD patients.




\section{Kidney Blood Pressure Research}

Zhou et al.: Irisin and Volume Overload are Associated with PEW in PD Patients

\section{Introduction}

Protein energy wasting (PEW) is prevalent among chronic kidney disease (CKD) patients and dialysis patients, and it is a marker of complications that lead to adverse outcomes in those patients $[1,2]$. Causes of PEW are complex, including uremia, dialysis intervention (nutrient loss and bio-incompatibility), inadequate nutrient (protein and energy) consumption, hypermetabolism (micro-inflammation), hormone dysregulation (hyperparathyroidism, insulin resistance, and insulin growth factor 1 resistance), as well as social and psychological factors [1-3]. The pathogenesis of PEW is unclear.

Irisin is an adipomyokine that was first identified in 2012. The precursor of irisin is fibronectin type III domain containing 5 (FNDC5). Irisin can increase energy expenditure by breaking down body fat and converting it into brown adipose tissue. In regard to whether the synthesis and secretion of irisin is influenced by the presence of CKD, some studies found that irisin levels were relatively lower in CKD patients, including maintenance dialysis patients, when compared to those of the healthy subjects $[4,5]$. In our previous study, we found that urotensin II and irisin are correlated with PEW in hemodialysis patients [6]. However, there is not enough study present that can elucidate irisin's role in peritoneal dialysis (PD) patients.

On the other hand, volume overload is a frequent complication in PD patients, and has been an independent predictor of all-cause or cardiovascular mortality in patients on dialysis. Malnourished patients with CKD will be more susceptible to volume overload compared with well-nourished patients [7]. However, it is not reported whether volume overload is associated with irisin levels in PD patients. We hypothesize that serum irisin levels and volume overload may induce PEW in PD patients. Additionally, volume overload may inhibit the synthesis and secretion of irisin from skeletal muscle, which aggravates PEW. The aim of this study is to investigate the relationships between serum irisin levels, volume overload, and PEW in PD patients.

\section{Materials and Methods}

\section{Study population}

From July 2016 to September 2016, 160 clinically stable PD patients were recruited from Peking University Third Hospital. Patients were eligible for inclusion if they (1) had been on peritoneal dialysis for at least 3 months; (2) agree with participating in this study. The exclusion criteria are that patients (1) have heave proteinuria ( $>3.5 \mathrm{~g} / \mathrm{d}$ ); (2) have concurrent diagnosis of hepatic cirrhosis or inflammatory diseases, such as acute infective peritonitis; (3) are in clinically unstable conditions with life expectancy that is less than 6 months. 35 healthy subjects were selected as the control group. All subjects provided written informed consent. The protocol of this study was approved by Peking University Third Hospital ethical committee.

\section{Assessment of biochemical parameters (irisin included)}

Participants' blood samples were collected after fasting for $12 \mathrm{~h}$. We collected the blood and anthropometric data in the subsequent week. Parts of the serum and plasma were stored at $-80^{\circ} \mathrm{C}$ and were not thawed until analysis. Serum irisin concentrations were measured using enzyme-linked immunosorbent assay (ELISA) kits (Phoenix Pharmaceuticals, Burlingame, CA, USA) in accordance with the manufacturer's instructions. The sensitivity of the assay was $0.1 \mathrm{ng} / \mathrm{ml}$ and the linear range of the standard was $0.1-1000 \mathrm{ng} /$ $\mathrm{ml}$. The intra- and inter-assay coefficients of variation (CV) were $4.5 \%$ and $8 \%$, respectively.

Hemoglobin was measured by colorimetry. Serum creatinine was measured by picrate method, and uric acid (UA) was measured by uricase method. Serum albumin was determined by exploring bromocresol green method. Serum total cholesterol (T-CHO), low-density lipoprotein cholesterol (LDL-C), triglyceride (TG), and high-density lipoprotein cholesterol (HDL-C) were measured enzymatically. Fasting blood glucose (FBG) was determined by glucose oxidase method. We collected 24 hours urine of PD patients that have 


\section{Kidney Blood Pressure Research}

Zhou et al.: Irisin and Volume Overload are Associated with PEW in PD Patients

more than $200 \mathrm{ml}$ of urine within 24 hours, and 24 hours dialysate effluent of all PD patients. 24 hours urinary protein excretion and dialysate protein loss were measured by biuret method.

\section{Body composition measurement}

152 PD patients and all the healthy subjects measured body composition by Body Composition Monitor (BCM, Fresenius Medical Care AG\&CO., KGaA D-61346 Bad Homburg, Germany). We collected data including volume status defined by overhydration value $(\mathrm{OH}, \mathrm{L})$, body mass index (BMI, $\mathrm{kg} / \mathrm{m} 2)$, body fat (\% and $\mathrm{kg})$, lean body mass $(\mathrm{kg})$, and muscle mass $(\mathrm{kg})$. To evaluate volume status of dialysis patients, $\mathrm{OH}$ has been proved to be reasonable $[8,9]$. According to our unit's previous study [10], we defined OH value higher than 2 liters as the cutoff threshold for volume overload in this study.

\section{Physical activity assessment}

The subjects' physical activity was assessed according to the international physical activity questionnaire (IPAQ) long forms [11]. All the recruited subjects did not exercise intentionally. Physical activity types consist of work-related activity (walking, moderate physical activity, and vigorous physical activity), transportation-related activity (walking and bicycling), domestic and garden-related activity (moderate physical activity and vigorous physical activity), as well as leisure-related activity (walking, moderate physical activity, and vigorous physical activity). Walking: METs=3.4METs*walking time; moderate physical activity: METs=4METs*activity time; vigorous physical activity: METs=8 METs*activity time. For calculating the subject's total physical activity, the formula is as follows: METs=sum of total work +total transport +total domestic and garden+total leisure time MET-minutes/week scores.

\section{Assessment of protein energy wasting (PEW)}

According to the International Society of Renal Nutrition and Metabolism (ISRNM) diagnostic criteria of PEW [12], indicators of PEW consist of 4 main categories :1) Biochemical parameters: serum albumin < $38 \mathrm{~g} / \mathrm{L}$, or total cholesterol $<100 \mathrm{mg} / \mathrm{dL} ; 2$ ) Body mass: body mass index (BMI) $<23.0 \mathrm{~kg} / \mathrm{m} 2$, unintentional weight loss ( $5 \%$ over 3 months or $10 \%$ over 6 months), or total body fat percentage <10\%; 3) Muscle mass: reduced muscle mass ( $5 \%$ over 3 months or $10 \%$ over 6 months), or reduced mid-arm muscle circumference area (reduction $>10 \%$ in relation to 50 th percentile of reference population); and 4) Dietary intake: unintentional low DPI( $<0.80 \mathrm{~g} \mathrm{~kg}-1$ day- 1 for at least 2 months), or unintentional low DEI $(<25 \mathrm{kcal}$ kg-1 day-1 for at least 2 months). Dietary assessment was performed by a dedicated dietitian on the basis of PD patients' dietary records for 3 days. Dietary protein intake was calculated and normalized with each patient's ideal body weight $(\mathrm{kg})$, i.e. height $(\mathrm{cm})$ minus 105 . At least three out of the four categories and at least one test in each of the categories must be satisfied for the diagnosis of PEW.

\section{Statistical analysis}

Data was expressed as means \pm standard deviation for normal distribution data or median $(25 \%-75 \%$ quartile) for non-normal distribution data. To compare the differences of numerical variables in two groups, we used independent Student's t-test for normal distribution, and non-parameter test for non-normal distribution. Chi-square test was used to compare categorical variables. For covariance analysis, Pearson correlation analysis and Spearman correlation analysis were used. Binary logistic analysis was performed to analyze the risk factors. All statistical analyses were performed using the statistical package 17.0 (IBM, Armonk, NY, USA).

\section{Results}

Comparison of clinical characteristics (consisting of serum irisin) between PD patients and normal control subjects

The clinical characteristics and biochemical data of PD patients and the control group were summarized in Table 1. There were 77 males and 83 females in PD group. The primary renal diseases of the PD patients were diabetic nephropathy (42 patients), chronic glomerulonephritis (52 patients), hypertensive glomerulosclerosis (14 patients), chronic 


\section{Kidney Blood Pressure Research}

Zhou et al.: Irisin and Volume Overload are Associated with PEW in PD Patients

Table 1. Comparison of clinical parameters between PD patients and normal control subjects. DM=diabetes mellitus; $\mathrm{Hb}=$ Hemoglobin; FBG=Fasting blood glucose; SBP=systolic blood pressure; TG=triglyceride; HDLch=high density lipoprotein cholesterol; LDL-ch=low density lipoprotein cholesterol; IPAQ=International physical activity questionnaire; $\mathrm{BMI}=$ body mass index

\begin{tabular}{|c|c|c|c|}
\hline Variables & $\begin{array}{c}\text { Normal control } \\
(n=35)\end{array}$ & $\begin{array}{c}\text { PD patients } \\
(\mathrm{n}=160)\end{array}$ & P Value \\
\hline Age (years) & $59 \pm 13.9$ & $58 \pm 13.4$ & 0.695 \\
\hline Gender $\mathrm{M} / \mathrm{F}$ ) & $18 / 17$ & $77 / 83$ & 0.723 \\
\hline Dialysis vintage (months) & - & $55 \pm 41$ & - \\
\hline $\mathrm{DM} /$ non-DM & - & $56 / 104$ & - \\
\hline $\mathrm{SBP}(\mathrm{mmHg})$ & $123 \pm 14.2$ & $133 \pm 18.0$ & 0.018 \\
\hline FBG $(\mathrm{mmol} / \mathrm{L})$ & $5.1(4.9,5.6)$ & $5.7(5.0,7.3)$ & 0.017 \\
\hline $\mathrm{Hb}(\mathrm{g} / \mathrm{L})$ & $147.8 \pm 11.9$ & $116.2 \pm 16.6$ & $<0.001$ \\
\hline Uric acid $(\mu \mathrm{mol} / \mathrm{L})$ & $345.4 \pm 85.8$ & $394.7 \pm 73.6$ & 0.001 \\
\hline Serum creatinine $(\mu \mathrm{mol} / \mathrm{L})$ & $76.1 \pm 11.4$ & $933.0 \pm 240.0$ & $<0.001$ \\
\hline Serum potassium $(\mathrm{mmol} / \mathrm{L})$ & $4.2 \pm 0.2$ & $4.4 \pm 0.7$ & 0.256 \\
\hline Serum albumin $(\mathrm{g} / \mathrm{L})$ & $46.0 \pm 1.9$ & $37.0 \pm 3.7$ & $<0.001$ \\
\hline $\mathrm{Ca}(\mathrm{mmol} / \mathrm{L})$ & $2.2 \pm 0.4$ & $2.5 \pm 0.2$ & $<0.001$ \\
\hline $\mathrm{P}(\mathrm{mmol} / \mathrm{L})$ & $1.3 \pm 0.4$ & $1.6 \pm 0.4$ & $<0.001$ \\
\hline $\mathrm{TG}(\mathrm{mmol} / \mathrm{L})$ & $1.4(1.0,2.4)$ & $1.9(1.3,3.0)$ & 0.012 \\
\hline LDL-ch $(\mathrm{mmol} / \mathrm{L})$ & $3.0 \pm 0.7$ & $2.8 \pm 0.8$ & 0.117 \\
\hline HDL-ch $(\mathrm{mmol} / \mathrm{L})$ & $1.1(1.0,1.3)$ & $1.0(0.8,1.1)$ & 0.002 \\
\hline $\begin{array}{l}\text { IPAQ scores (long term) } \\
\text { (minutes/week) }\end{array}$ & $1513 \pm 390$ & $1428(408,1428)$ & 0.002 \\
\hline BMI (kg/m2) & $25.3 \pm 4.4$ & $23.7 \pm 3.5$ & 0.028 \\
\hline Body fat proportion (\%) & $30.5 \pm 7.1$ & $39.5 \pm 1.4$ & $<0.001$ \\
\hline Body fat mass $(\mathrm{kg})$ & $20.2 \pm 6.8$ & $25.5 \pm 10.8$ & $<0.001$ \\
\hline Lean body mass ( $\mathrm{kg}$ ) & $45.3 \pm 9.0$ & $38.4 \pm 10.9$ & $<0.001$ \\
\hline Muscle mass $(\mathrm{kg})$ & $42.3 \pm 8.6$ & $35.2 \pm 9.3$ & $<0.001$ \\
\hline Serum irisin $(\mathrm{ng} / \mathrm{ml})$ & $464.2 \pm 37.4$ & $113.2 \pm 11.8$ & $<0.001$ \\
\hline
\end{tabular}

interstitial nephritis (17 patients), renal atherosclerosis (6 patients), other causes (13 patients), and unknown causes (16 patients). Mean dialysis treatment vintage was $55 \pm 41$ months.

PD patients had higher level of systolic blood pressure, serum uric acid, serum creatinine, calcium, phosphate, triglyceride, body fat proportion, and body fat mass than those of the healthy subjects. In contrast, hemoglobin, serum albumin, HDL-ch, serum irisin, IPAQ scores, BMI, lean body mass and muscle mass were significantly lower $(\mathrm{P}<0.05)$ in PD patients in comparison to those of the normal controls.

\section{Correlated analysis of irisin with other parameters in PD patients}

In PD patients, bivariate correlation analysis revealed that serum irisin was negatively correlated with LDL-ch $(\mathrm{r}=-0.177, \mathrm{P}=0.026)$, body fat mass $(\mathrm{r}=-0.227, \mathrm{P}=0.002)$, and body fat proportion $(\mathrm{r}=-0.279, \mathrm{P}<0.001)$, but was positively correlated with age $(\mathrm{r}=0.161$, $\mathrm{P}=0.028)$, muscle mass $(\mathrm{r}=0.284, \mathrm{P}=<0.001)$, and lean body mass $(\mathrm{r}=0.271, \mathrm{P}=<0.001)$. We did not observe a significant correlation between irisin, sex, hemoglobin, KT/V, BMI, serum creatinine, serum uric acid, and HDL-ch. In addition, serum irisin levels were not correlated with international physical activity scores in our current study (Table 2).

Comparison of parameters (consisting of irisin) between PD patients with PEW and without PEW

Our data showed that irisin level is lower in PEW group when compared to that of nonPEW group. PEW group tend to be older, while serum albumin, serum creatinine, and muscle mass are lower in comparison to those of non-PEW group. Additionally, volume overload proportion and hs-CRP in PEW group are significantly higher than those of non-PEW group. Less than 1/3 (52/160) PD patients had residual kidney function. Our results showed that there was no difference in dialysate protein loss between PEW group and non-PEW group, and there was no difference in proteinuria levels between PEW group and non- PEW group (Table 3).

Prevalence of four diagnostic components of PEW is as follows: Low serum albumin was 79.5\%; Low body mass in PEW was 48.2\%; Prevalence of muscle mass loss in PEW was $72.3 \%$; Low ideal DPI or ideal DEI was $62.7 \%$. 


\section{Kidney Bloód Pressure Research}

Table 2. Correlation coefficients of irisin and other clinical parameters in PD patients. BMI=body mass index; $\mathrm{UA}=$ uric acid; $\mathrm{Hs}$ - $\mathrm{CRP}=$ high-sensitivity $\mathrm{C}$-reactive protein; $\mathrm{TG}=$ triglyceride; $\mathrm{HDL}$-ch= high density lipoprotein cholesterol; LDL-ch=low density lipoprotein cholesterol; IPAQ=international physical activity questionnaire

\begin{tabular}{|c|c|c|}
\hline Variables & & $P$ \\
\hline Age (years) & $\frac{\mathrm{T}}{0.161}$ & $\frac{\mathrm{r}}{0.028}$ \\
\hline Gender(M/F) & 0.002 & 0.977 \\
\hline Hemoglobin $(\mathrm{g} / \mathrm{L})$ & -0.076 & 0.343 \\
\hline KT/V(per week) & $\begin{array}{l}-0.010 \\
-0.083\end{array}$ & 0.304 \\
\hline BMI $(\mathrm{kg} / \mathrm{m} 2)$ & 0.017 & 0.831 \\
\hline Serum albumin $(\mathrm{g} / \mathrm{L})$ & -0.103 & 0.200 \\
\hline Serum creatinine $(\mu \mathrm{mol} / \mathrm{L})$ & 0.063 & 0.431 \\
\hline $\mathrm{UA}(\mu \mathrm{mol} / \mathrm{L})$ & 0.018 & 0.822 \\
\hline Hs-CRP (mg/L) & 0.077 & 0.335 \\
\hline $\mathrm{TG}(\mathrm{mmol} / \mathrm{L})$ & 0.030 & 0.711 \\
\hline HDL-ch $(\mathrm{mmol} / \mathrm{L})$ & -0.052 & 0.518 \\
\hline LDL-ch $(\mathrm{mmol} / \mathrm{L})$ & -0.177 & 0.026 \\
\hline IPAQ scores(long term) (minutes/week) & 0.019 & 0.817 \\
\hline $\begin{array}{l}\text { Muscle mass }(\mathrm{kg}) \\
\text { Body fat mass }(\mathrm{kg})\end{array}$ & $\begin{array}{c}0.284 \\
-0.227\end{array}$ & $\begin{array}{c}<0.001 \\
0.002\end{array}$ \\
\hline Body fat proportion (\%) & -0.279 & $<0.001$ \\
\hline Lean body mass $(\mathrm{kg})$ & 0.271 & $<0.001$ \\
\hline
\end{tabular}

Table 3. Comparison of clinical parameters between PD patients with PEW and without PEW. DM=diabetes mellitus; $\mathrm{UA}=$ uric acid; $\mathrm{SBP}=$ systolic blood pressure; $\mathrm{PTH}=$ parathyroid hormone; $\mathrm{TG}=$ triglyceride; HDL-ch= high density lipoprotein cholesterol; LDL-ch=low density lipoprotein cholesterol; Hs-CRP=high-sensitivity C-reactive protein

\begin{tabular}{|c|c|c|c|}
\hline Variables & $\begin{array}{l}\text { Non-PEW group } \\
(n=77)\end{array}$ & $\begin{array}{c}\text { PEW group } \\
(n=83)\end{array}$ & P Value \\
\hline Age (years) & $56 \pm 13.1$ & $61 \pm 13.4$ & 0.021 \\
\hline Gender $(M / F)$ & $38 / 39$ & $39 / 44$ & 0.765 \\
\hline Dialysis vintage (Months) & $57.3 \pm 46.0$ & $52.2 \pm 35.2$ & 0.435 \\
\hline $\mathrm{DM} /$ non-DM & $25 / 52$ & $31 / 52$ & 0.518 \\
\hline $\mathrm{SBP}(\mathrm{mmHg})$ & $134 \pm 19.4$ & $131 \pm 16.5$ & 0.366 \\
\hline Hemoglobin $(\mathrm{g} / \mathrm{L})$ & $117.5 \pm 17.1$ & $115.1 \pm 16.1$ & 0.350 \\
\hline Serum creatinine $(\mu \mathrm{mol} / \mathrm{L})$ & $1005.1 \pm 242.9$ & $866.1 \pm 218.0$ & $<0.001$ \\
\hline $\mathrm{UA}(\mu \mathrm{mol} / \mathrm{L})$ & $403.2 \pm 86.6$ & $386.8 \pm 58.4$ & 0.166 \\
\hline $\mathrm{CO} 2 \mathrm{CP}(\mathrm{mmol} / \mathrm{L})$ & $25.6 \pm 2.9$ & $25.5 \pm 2.6$ & 0.820 \\
\hline Hs-CRP(mg/L) & $2.5(2.0,5.9)$ & $4.5(2.5,11.7)$ & 0.005 \\
\hline Serum albumin $(\mathrm{g} / \mathrm{L})$ & $38.3 \pm 3.4$ & $35.8 \pm 3.5$ & $<0.001$ \\
\hline $\mathrm{Ca}(\mathrm{mmol} / \mathrm{L})$ & $2.4 \pm 0.2$ & $2.5 \pm 0.2$ & 0.499 \\
\hline $\mathrm{p}(\mathrm{mmol} / \mathrm{L})$ & $1.7 \pm 0.4$ & $1.6 \pm 0.4$ & 0.115 \\
\hline PTH $(\mathrm{pg} / \mathrm{ml})$ & $154.0(87.8,327.5)$ & $144.2(62.7,278.0)$ & 0.295 \\
\hline $\mathrm{TG}(\mathrm{mmol} / \mathrm{L})$ & $2.0(1.4,3.1)$ & $1.8(1.3,2.8)$ & 0.160 \\
\hline LDL-ch $(\mathrm{mmol} / \mathrm{L})$ & $2.7 \pm 0.8$ & $2.9 \pm 0.8$ & 0.325 \\
\hline HDL-ch $(\mathrm{mmol} / \mathrm{L})$ & $1.0(0.8,1.1)$ & $1.0(0.9,1.2)$ & 0.088 \\
\hline KT/V(per week) & $1.9 \pm 0.3$ & $1.9 \pm 0.3$ & 0.464 \\
\hline Dialysis KT/V(per week) & $1.7 \pm 0.3$ & $1.8 \pm 0.3$ & 0.056 \\
\hline Residual kidney KT/V(per week) & $0.0(0.0,0.2)$ & $0.0(0.0,0.2)$ & 0.239 \\
\hline Dialysate protein loss $(\mathrm{g} / \mathrm{d})$ & $4.2 \pm 0.3$ & $4.4 \pm 0.5$ & 0.241 \\
\hline 24 hours proteinuria excretion $(\mathrm{g})$ & $1.0 \pm 0.7$ & $1.1 \pm 0.8$ & 0.455 \\
\hline Body fat mass ( $\mathrm{kg})$ & $26.3 \pm 11.1$ & $24.7 \pm 10.4$ & 0.369 \\
\hline Body fat proportion (\%) & $39.0 \pm 1.4$ & $40.0 \pm 1.4$ & 0.675 \\
\hline Muscle mass $(\mathrm{kg})$ & $37.5 \pm 9.3$ & $33.2 \pm 8.9$ & 0.004 \\
\hline Lean body mass ( $\mathrm{kg})$ & $39.9 \pm 10.1$ & $37.0 \pm 11.5$ & 0.096 \\
\hline $\mathrm{OH} \geqslant 2$ liters $/ \mathrm{OH}<2$ liters & $30 / 41$ & $50 / 31$ & 0.016 \\
\hline Serum irisin $(\mathrm{ng} / \mathrm{ml})$ & $117.4 \pm 17.6$ & $106.5 \pm 15.2$ & $<0.001$ \\
\hline
\end{tabular}

Comparison of clinical parameters between volume overload ( $\mathrm{OH} \geq 2$ liters) group and normal volume $(\mathrm{OH}<2$ liters) group in $\mathrm{PD}$ patients

We observed no significant difference of serum irisin level between volume overload $(\mathrm{OH} \geq 2$ liters) group and normal volume $(\mathrm{OH}<2$ liters) group in $\mathrm{PD}$ patients. In $\mathrm{OH} \geq 2$ liters group, the proportions of male patients and diabetes mellitus are higher than those of $\mathrm{OH}<2$ liters group. In addition, hemoglobin, systolic blood pressure, hs-CRP, muscle mass, and lean 


\section{Kidney Blood Pressure Research}

Zhou et al.: Irisin and Volume Overload are Associated with PEW in PD Patients

Table 4. Comparison of clinical parameters of volume overload $(\mathrm{OH} \geq 2$ liters) group and normal volume $(\mathrm{OH}<2$ liters $)$ group in PD patients. $\mathrm{DM}=$ diabetes mellitus; $\mathrm{UA}=$ uric acid; $\mathrm{SBP}=$ systolic blood pressure; $\mathrm{PTH}=$ parathyroid hormone; $\mathrm{TG}=$ triglyceride; $\mathrm{TCHO}=$ total cholesterol; Hs-CRP=high-sensitivity $\mathrm{C}$-reactive protein

\begin{tabular}{|c|c|c|c|}
\hline Variables & $\begin{array}{c}\mathrm{OH} \geq 2 \text { liters group } \\
(\mathrm{n}=80)\end{array}$ & $\begin{array}{c}\mathrm{OH}<2 \text { liters group } \\
(\mathrm{n}=72)\end{array}$ & P value \\
\hline Age (years) & $57 \pm 13.5$ & $60 \pm 13.0$ & 0.189 \\
\hline Gender $(M / F)$ & $50 / 30$ & $22 / 50$ & $<0.001$ \\
\hline Dialysis vintage (Months) & $51.4 \pm 41.4$ & $57.8 \pm 40.7$ & 0.344 \\
\hline DM/non-DM & $38 / 42$ & $16 / 56$ & 0.001 \\
\hline SBP (mmHg) & $136 \pm 16.6$ & $128.5 \pm 19.3$ & 0.010 \\
\hline Hemoglobin (g/L) & $131.1 \pm 17.4$ & $119.6 \pm 15.6$ & 0.017 \\
\hline Serum creatinine $(\mu \mathrm{mol} / \mathrm{L})$ & $923.2 \pm 239.0$ & $941.3 \pm 246.3$ & 0.647 \\
\hline $\mathrm{UA}(\mu \mathrm{mol} / \mathrm{L})$ & $386.3 \pm 73.1$ & $409.1 \pm 73.7$ & 0.057 \\
\hline $\mathrm{CO} 2 \mathrm{CP}(\mathrm{mmol} / \mathrm{L})$ & $25.9 \pm 2.6$ & $25.1 \pm 2.8$ & 0.066 \\
\hline $\mathrm{Hs}-\mathrm{CRP}(\mathrm{mg} / \mathrm{L})$ & $3.4(2.5,9.6)$ & $3.2(0.9,6.3)$ & 0.048 \\
\hline Serum albumin $(\mathrm{g} / \mathrm{L})$ & $36.4 \pm 3.5$ & $37.7 \pm 3.8$ & 0.027 \\
\hline $\mathrm{Ca}(\mathrm{mmol} / \mathrm{L})$ & $2.4 \pm 0.2$ & $2.5 \pm 0.2$ & 0.495 \\
\hline $\mathrm{p}(\mathrm{mmol} / \mathrm{L})$ & $1.6 \pm 0.4$ & $1.6 \pm 0.4$ & 0.358 \\
\hline PTH $(\mathrm{pg} / \mathrm{ml})$ & $152.4(76.3,317.2)$ & $148.7(66.1,302.3)$ & 0.773 \\
\hline $\mathrm{TG}(\mathrm{mmol} / \mathrm{L})$ & $1.7(1.2,2.6)$ & $2.2(1.6,3.3)$ & 0.013 \\
\hline TCHO $(\mathrm{mmol} / \mathrm{L})$ & $4.5 \pm 1.0$ & $5.0 \pm 1.1$ & 0.006 \\
\hline LDL-ch $(\mathrm{mmol} / \mathrm{L})$ & $2.7 \pm 0.7$ & $2.8 \pm 0.8$ & 0.292 \\
\hline HDL-ch $(\mathrm{mmol} / \mathrm{L})$ & $1.0(0.8,1.1)$ & $1.0(0.8,1.1)$ & 0.914 \\
\hline Serum irisin $(\mathrm{ng} / \mathrm{ml})$ & $112.6 \pm 12.1$ & $113.1 \pm 11.8$ & 0.813 \\
\hline
\end{tabular}

Table 5. Bivariate logistic regression analysis of PEW in PD patients. $\mathrm{CI}=$ confident interval; $\mathrm{DM}=$ diabetes mellitus; Hs-CRP= high-sensitivity C-reactive protein

\begin{tabular}{cccc}
\hline Variables & EXP(B) & P value & 95\% CI for EXP(B) \\
\hline Constant & & $<0.001$ & \\
Age(years) & 1.000 & 0.995 & $0.960-1.042$ \\
DM/non-DM & 0.918 & 0.863 & $0.350-2.412$ \\
Hs-CRP(mg/L) & 1.043 & 0.182 & $0.880-1.110$ \\
Muscle mass (kg) & 0.933 & 0.021 & $0.116-0.929$ \\
OH<2 liters/OH $\geq 2$ liters & 0.328 & 0.036 & $0.776-0.891$ \\
Serum irisin $(\mathrm{ng} / \mathrm{ml})$ & 0.831 & 0.000 & $0.614-0.900$ \\
Serum albumin (g/L) & 0.744 & 0.002 & \\
\hline
\end{tabular}

are also higher in $\mathrm{OH} \geq 2$ liters group. Serum albumin, $\mathrm{TG}$ and $\mathrm{TCHO}$ are lower in $\mathrm{OH} \geq 2$ liters group in comparison to those of $\mathrm{OH}<2$ liters group (Table 4).

Bivariate logistic regression analysis of the determinant factors of PEW in PD patients

A bivariate logistic regression model (the variables entered by univariate analysis $\mathrm{P} \leqslant 0.1$ or those variables suspected to be correlated with PEW) was conducted to assess which kinds of clinical factors were independently associated with PEW. The results showed that serum irisin, serum albumin, volume overload, and muscle mass were independently associated with PEW, while age, diabetes mellitus and hs-CRP were excluded from our model (Table 5).

\section{Discussion}

Naicker et al. reported a very high prevalence of PEW (76.2\%) [13] in PD patients. Similarly, Prasad et al $[14,15]$. verified that $74.91 \%$ of PD patients had malnutrition in Indian population. In our current study, 51.9\% of PD patients had PEW. The prevalence is lower when compared to other cross-sectional studies. The exact reason is unclear for the differences of results. Causes of PEW in PD patients are complex, including low energy intake induced by anorexia, loss of nutrients due to dialysis, dietary restriction, increased protein catabolism, acidosis [15], as well as severe peritoneal protein loss which is aggravated due to 


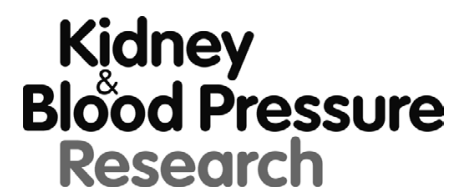

\begin{tabular}{l|l}
\hline Kidney Blood Press Res 2017;42:1216-1224 \\
\hline DOI: 10.1159/000485925 & (c) 2017 The Author(s). Published by S. Karger AG, Basel \\
Published online: December 14, 2017 & www.kargercom/kbr
\end{tabular}

Zhou et al.: Irisin and Volume Overload are Associated with PEW in PD Patients

peritoneal infections [16]. At present, the pathogenesis of PEW is still unclear.

Our previous study proved that serum irisin levels of hemodialysis patients are lower in comparison to those of the healthy controls [6]. In our current study, PD patients also have lower irisin levels than the healthy subjects in the control group. Possible reasons for this finding are sarcopenia, which is common in CKD patients, with decrease of irisin production from muscle cells, and indoxyl sulfate-induced inhibition of the expression of FNDC5, which is the precursor of irisin [17]. Ebert T et al. reported correlations between irisin and LDLch, TCHO (inverse correlation) [5]. In our study, serum irisin levels are correlated with LDL-ch (inverse correlation), body composition markers like muscle mass, lean body mass (positive correlation), and body fat mass (inverse correlation). This can be explained by the fact that muscle cells are the main source of circulating irisin even though fat can also secrete this factor. We may consider it subordinate in PD patients. While it was suggested that exercise can stimulate the synthesis of irisin [18], the effects of chronic exercise on irisin still remain controversial. Under the condition that no PD patient was put on intentional exercise regimen, we assessed the subjects' physical activity and found lower IPAQ scores of PD patients compared to those of healthy controls; however, no direct correlation was found between serum irisin and IPAQ scores in PD patients. Even though PD patients had lower serum irisin levels, we tend to believe that exercise may not be a main regulating factor of irisin. Reduced irisin levels were observed in malnutrition subjects with other diseases such as chronic heart failure and anorexia nervosa $[18,19]$. He et al. found that hemodialysis patients with PEW had lower irisin level than those without PEW; meanwhile, lower irisin levels were correlated with PEW [6]. In our current study, we are the first to verify that serum irisin levels are significantly lower in PD patients with PEW compared to those without PEW, and serum irisin is an independent predictor of PEW in PD patients. Reduced muscle mass might be the cause of lower irisin levels in PD patients with PEW. As a myokine factor, irisin regulates skeletal muscle metabolism, which reduces muscle atrophy in mice [20]. Moreover, it was observed that the decrease of myosin type II expression was completely prevented by $r$-Irisin administration in mice. With the animal experiment results, we may speculate that irisin can be used as a new treatment method for PEW in CKD patients, and this is worthy of further study.

Another important question is whether proteinuria is associated with PEW. In fact, when we diagnosed hypo-albumineia $(<38 \mathrm{~g} / \mathrm{L})$, we excluded heavy proteinuria and hepatic cirrhosis; moreover, there was no difference in proteinuria levels between PEW group and non-PEW group. We want to elucidate whether dialysate protein loss is associated with PEW. Our results showed that there was no difference in dialysate protein loss between PEW group and non-PEW group. In our previous study, we found that serum irisin levels were negatively associated with proteinuria in diabetic nephropathy patients [21]. In our current study, we did not demonstrate the association between serum irisin and proteinuria, which may be because we excluded PD patients with heavy proteinuria and only few patients had residual renal function.

The IPOD-PD study [22] showed that volume overload $>1.1 \mathrm{~L}$ occurred in $56.5 \%$ of PD patients. We found that the prevalence of volume overload by bioimpedance analysis in PD patients was $52.6 \%$, which is similar to the reported proportion. Our results verified that male to female ratio was higher in volume overload group than that of normal volume group, which may be explained by men's relatively poor compliance to control their dietary intake of sodium and water. In regard to the relationship between volume overload and PEW in PD patients, a positive correlation was suggested with the explanation that volume overload acts as an inflammatory stimulus by immune activation resulting from poor tissue perfusion, which was supported by our result of hs-CRP, and bowel edema-induced translocation of bowel endotoxins into the circulation [23]. Moreover, volume overload is also an independent predictor of PEW. However, there is no significant difference in irisin levels between normohydration group and overhydration group, so we speculate that volume overload may not induce PEW through affecting myokine irisin pathways in PD patients. 


\section{Kidney \\ Blood Pressure Research}

Zhou et al.: Irisin and Volume Overload are Associated with PEW in PD Patients

There are several limitations in our current study. The sample size is relatively small. Further animals experiment and cells experiment are needed to confirm our viewpoint.

\section{Conclusion}

Our results are the first to elucidate that serum irisin levels and volume overload are closely associated with PEW in PD patients. However, volume overload has no direct relationship with irisin levels. Our results hint that irisin supplement may be a new therapeutic direction for ameliorating PEW in PD patients. Strict volume control strategies are also important in improving nutrition status in dialysis patients.

\section{Disclosure Statement}

The authors report no Disclosure Statement. The authors alone are responsible for the content and writing of this paper.

\section{Acknowledgements}

This study was supported by National Natural Science Foundation (Grant No. 81570663, Grant No. 81170706, and Grant No. 81341022) to Ai-Hua Zhang. Major diseases of funding of Beijing Municipal Science \& technology commission (No. SCW 2009-8) to Ai-Hua Zhang.

\section{References}

1 Carrero JJ, Stenvinkel P, Cuppari L, Ikizler TA, Kalantar-Zadeh K, Kaysen G, Mitch WE, Price SR, Wanner C, Wang AY, ter Wee P, Franch HA: Etiology of the protein-energy wasting syndrome in chronic kidney disease: A consensus statement from the International Society of Renal Nutrition and Metabolism (ISRNM). J Ren Nutr 2013;23:77-90.

2 Sukkar SG, Gallo F, Borrini C, Vaccaro A, Marchello C, Boicelli R, Borgarelli C, Solari P, Ratto CE, Ravera G: Effects of a new mixture of essential amino acids (Aminotrofic(®)) in malnourished haemodialysis patients. Med J Nutrition Metab 2012;5:259-266.

- 3 Liu Y, Xiao X, Qin DP, Tan RS, Zhong XS, Zhou DY, Liu Y, Xiong X, Zheng YY: Comparison of intradialytic parenteral nutrition with glucose or amino acid mixtures in maintenance hemodialysis patients. Nutrients 2016;8.

4 Wen MS, Wang CY, Lin SL, Hung KC: Decrease in irisin in patients with chronic kidney disease. PLoS One 2013;8:e64025.

5 Ebert T, Focke D, Petroff D, Wurst U, Richter J, Bachmann A, Lossner U, Kralisch S, Kratzsch J, Beige J, Bast I, Anders M, Bluher M, Stumvoll M, Fasshauer M: Serum levels of the myokine irisin in relation to metabolic and renal function. Eur J Endocrinol 2014;170:501-506.

-6 He WY, Wu F, Pang XX, Chen GJ, A LT, He L, Wang S, Tang CS, Zhang AH: Irisin is associated with urotensin II and protein energy wasting in hemodialysis patients. Kidney Blood Press Res 2016;41:78-85.

7 Ohashi Y, Saito A, Yamazaki K, Tai R, Matsukiyo T, Aikawa A, Sakai K: Brain natriuretic peptide and body fluid composition in patients with chronic kidney disease: A Cross-Sectional study to evaluate the relationship between volume overload and malnutrition. Cardiorenal Med 2016;6:337-346.

-8 Crepaldi C, Soni S, Chionh CY, Wabel P, Cruz DN, Ronco C: Application of body composition monitoring to peritoneal dialysis patients. Contrib Nephrol 2009;163:1-6.

-9 Moissl UM, Wabel P, Chamney PW, Bosaeus I, Levin NW, Bosy-Westphal A, Korth O, Muller MJ, Ellegard L, Malmros V, Kaitwatcharachai C, Kuhlmann MK, Zhu F, Fuller NJ: Body fluid volume determination via body composition spectroscopy in health and disease. Physiol Meas 2006;27:921-933. 


\section{Kidney \\ Bloód Pressure Research}

Zhou et al.: Irisin and Volume Overload are Associated with PEW in PD Patients

10 Luo YJ, Wang T: What is the upper limitation of volume in Chinese peritoneal dialysis patients? Blood Purif 2011;31:289-295.

-11 Craig CL, Marshall AL, Sjostrom M, Bauman AE, Booth ML, Ainsworth BE, Pratt M, Ekelund U, Yngve A, Sallis JF, Oja P: International physical activity questionnaire: 12-Country reliability and validity. Med Sci Sports Exerc 2003;35:1381-1395.

12 Fouque D, Kalantar-Zadeh K, Kopple J, Cano N, Chauveau P, Cuppari L, Franch H, Guarnieri G, Ikizler TA, Kaysen G, Lindholm B, Massy Z, Mitch W, Pineda E, Stenvinkel P, Trevino-Becerra A, Wanner C: A proposed nomenclature and diagnostic criteria for protein-energy wasting in acute and chronic kidney disease. Kidney Int 2008;73:391-398.

13 Naicker S: Nutritional problems associated with end-stage renal disease in the developing world. Artif Organs 2002;26:757-759.

14 Prasad N, Gupta A, Sinha A, Sharma RK, Kumar A, Kumar R: Changes in nutritional status on follow-up of an incident cohort of continuous ambulatory peritoneal dialysis patients. J Ren Nutr 2008;18:195-201.

15 Stenvinkel P, Heimburger O, Lindholm B, Kaysen GA, Bergstrom J: Are there two types of malnutrition in chronic renal failure? Evidence for relationships between malnutrition, inflammation and atherosclerosis (MIA syndrome). Nephrol Dial Transplant 2000;15:953-960.

-16 Young GA, Kopple JD, Lindholm B, Vonesh EF, De Vecchi A, Scalamogna A, Castelnova C, Oreopoulos DG, Anderson GH, Bergstrom J, Et A: Nutritional assessment of continuous ambulatory peritoneal dialysis patients: An international study. Am J Kidney Dis 1991;17:462-471.

17 Bostrom P, Wu J, Jedrychowski MP, Korde A, Ye L, Lo JC, Rasbach KA, Bostrom EA, Choi JH, Long JZ, Kajimura S, Zingaretti MC, Vind BF, Tu H, Cinti S, Hojlund K, Gygi SP, Spiegelman BM: A PGC1-alpha-dependent myokine that drives brown-fat-like development of white fat and thermogenesis. Nature 2012;481:463468.

18 Stengel A, Hofmann T, Goebel-Stengel M, Elbelt U, Kobelt P, Klapp BF: Circulating levels of irisin in patients with anorexia nervosa and different stages of obesity--correlation with body mass index. Peptides 2013;39:125-130.

19 Matsuo Y, Gleitsmann K, Mangner N, Werner S, Fischer T, Bowen TS, Kricke A, Matsumoto Y, Kurabayashi M, Schuler G, Linke A, Adams V: Fibronectin type III domain containing 5 expression in skeletal muscle in chronic heart failure-relevance of inflammatory cytokines. J Cachexia Sarcopenia Muscle 2015;6:62-72.

20 Colaianni G, Mongelli T, Cuscito C, Pignataro P, Lippo L, Spiro G, Notarnicola A, Severi I, Passeri G, Mori G, Brunetti G, Moretti B, Tarantino U, Colucci SC, Reseland JE, Vettor R, Cinti S, Grano M: Irisin prevents and restores bone loss and muscle atrophy in hind-limb suspended mice. Sci Rep 2017;7:2811.

21 He WY, Bai Q, A LT, Tang CS, Zhang AH: Irisin levels are associated with urotensin II levels in diabetic patients. J Diabetes Investig 2015;6:571-576.

-22 Ronco C, Verger C, Crepaldi C, Pham J, De Los RT, Gauly A, Wabel P, Van Biesen W: Baseline hydration status in incident peritoneal dialysis patients: The initiative of patient outcomes in dialysis (IPOD-PD study) dagger. Nephrol Dial Transplant 2015;30:849-858.

-23 Niebauer J, Volk HD, Kemp M, Dominguez M, Schumann RR, Rauchhaus M, Poole-Wilson PA, Coats AJ, Anker SD: Endotoxin and immune activation in chronic heart failure: A prospective cohort study. Lancet 1999;353:1838-1842. 